\title{
Epstein-Barr Virus Early RNA
}

National Cancer Institute

\section{Source}

National Cancer Institute. Epstein-Barr Virus Early RNA. NCI Thesaurus. Code C111618.

Small non-coding RNA that is encoded by Epstein-Barr virus DNA and transcribed by virally-infected cells throughout the latent cycle. Expression of these oligonucleotides may be associated with the regulation of host ribosome function. 